"Corporate social responsibility of financial sector institutions in the light of sustainable development goals financing: the role of banks and stock exchanges"

\begin{tabular}{|c|c|}
\hline AUTHORS & $\begin{array}{l}\text { Inna Makarenko (D https://orcid.org/0000-0001-7326-5374 } \\
\mathbb{R} \text { http://www.researcherid.com/rid/AAE-8453-2020 } \\
\text { Yulia Yelnikova (D https://orcid.org/0000-0002-8478-4716 } \\
\text { R https://publons.com/researcher/2021543/yuliia-yelnikova/ } \\
\text { Anna Lasukova (D https://orcid.org/0000-0002-1929-4729 } \\
\text { Abdul Rahman Barhaq }\end{array}$ \\
\hline ARTICLE INFO & $\begin{array}{l}\text { Inna Makarenko, Yulia Yelnikova, Anna Lasukova and Abdul Rahman Barhaq } \\
\text { (2018). Corporate social responsibility of financial sector institutions in the light of } \\
\text { sustainable development goals financing: the role of banks and stock exchanges. } \\
\text { Public and Municipal Finance, } 7(3), 1-14 \text {. doi:10.21511/pmf.07(3).2018.01 }\end{array}$ \\
\hline DOI & http://dx.doi.org/10.21511/pmf.07(3).2018.01 \\
\hline RELEASED ON & Tuesday, 06 November 2018 \\
\hline RECEIVED ON & Saturday, 22 September 2018 \\
\hline ACCEPTED ON & Friday, 26 October 2018 \\
\hline LICENSE & $\begin{array}{l}(c) E Y \\
\text { This work is licensed under a Creative Commons Attribution } 4.0 \text { International } \\
\text { License }\end{array}$ \\
\hline JOURNAL & "Public and Municipal Finance" \\
\hline ISSN PRINT & $2222-1867$ \\
\hline ISSN ONLINE & $2222-1875$ \\
\hline PUBLISHER & LLC "Consulting Publishing Company "Business Perspectives" \\
\hline FOUNDER & LLC "Consulting Publishing Company "Business Perspectives" \\
\hline
\end{tabular}

NUMBER OF REFERENCES

62
NUMBER OF FIGURES

1

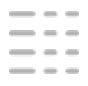

NUMBER OF TABLES

3

(C) The author(s) 2022. This publication is an open access article. 


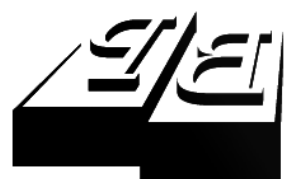

BUSINESS PERSPECTIVES

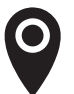

LLC "CPC "Business Perspectives" Hryhorii Skovoroda lane, 10, Sumy, 40022, Ukraine

www.businessperspectives.org

Received on: $22^{\text {nd }}$ of September, 2018 Accepted on: $26^{\text {th }}$ of October, 2018

\footnotetext{
(c) Limited Liability Company

"Consulting Publishing Company
}

"Business Perspectives", 2018

Inna Makarenko, Doctor of

Economics, Associate Professor, Accounting and Tax Department, Sumy State University, Ukraine.

Yulia Yelnikova, Ph.D., Assistant Professor, Accounting and Tax Department, Sumy State University, Ukraine.

Anna Lasukova, Ph.D., Senior Lecturer, Finance, Banking and Insurance Department, Sumy State University, Ukraine.

Abdul Rahman Barhaq, Deputy Chief Financial Officer, Afghanistan Central Bank, Afghanistan.
Inna Makarenko (Ukraine), Yulia Yelnikova (Ukraine), Anna Lasukova (Ukraine), Abdul Rahman Barhaq (Afghanistan)

\section{CORPORATE SOCIAL} RESPONSIBILITY OF FINANCIAL SECTOR INSTITUTIONS IN THE LIGHT OF SUSTAINABLE DEVELOPMENT GOALS FINANCING: THE ROLE OF BANKS
AND STOCK EXCHANGES

\begin{abstract}
Significant gap in investment resources for financing Sustainable Development Goals can be overcome with the revitalization of the corporate social responsibility mechanism of the financial sector institutions, for example banks and stock exchanges as the largest players in the global financial sector. The most relevant for them are Goals 1, 5, 8, 10, 13, 17 . Incorporating these goals into activities of the financial sector institutions requires not only the activation of their CSR mechanism in the directions indicated by the targets, but also the radical restructuring of all business processes and the reorientation of their overall sustainability strategy. Analysis of current sustainability reporting disclosure by financial sector institutions in global and regional aspects was conducted. Based on the analysis, the authors define the role of CSRs of banks and stock exchanges in SDG financing as follows: banks - ensuring their own sustainability and efficiency through CSR mechanisms, formation of new tools, methods and technologies of financial support of SDG; stock exchanges minimization of information asymmetry in investor decision making, taking into consideration ESG criteria, formation of exemplary disclosure practices and new markets and market benchmarks by listing companies.
\end{abstract}

\section{Keywords \\ sustainability, stakeholder, financial sector, financing, CSR mechanism}

\section{JEL Classification Q01, G21}

\section{INTRODUCTION}

In overcoming the consequences of the global 2007-2009 financial crisis, the Paris Agreement on Climate Agreements and the United Nations Sustainable Development Goals (SDGs UN 2030 Agenda and Sustainable Development Goals) mark new milestones in the development of the financial sector, the role of which is transformed due to the emergence of new investment opportunities. So, according to Ban Ki-moon, "green finance" offers extraordinary unlimited investment opportunities in developing countries. All financial players must work together to create a mechanism for implementing these opportunities.

The corporate social responsibility (CSR) of financial sector institutions as a holistic mechanism for responsible management of their activities is directly aimed at realizing such investment opportunities, overcoming key barriers to financing the SDG and eliminating the global investment gap of USD 5 to 7 trillion annually, including USD 3.3 to 4.5 trillion in developing countries. Developing countries face USD 2.5 trillion annual investment gap in key sustainable development sectors. 
Among the key barriers to financing the SDG are:

- the necessity to integrate a negative ecological externalities and ESG criteria into the practice of making investment decisions in the financial sector and market practice;

- consideration of new investment opportunities and their features in the strategy and tactics of the activities of financial institutions;

- formation of new competencies, types of sustainable development financing and its goals;

- overcoming information asymmetry among the investment process participants: forming common approaches to information disclosure and understanding ESG criteria;

- reorientation of financial instruments for longer-term financing.

According to the expert assessments, financing of sustainable development initiatives creates a new market of USD 70 trillion by 2030, business strategy varies according to environmental, social and governance factors (ESGs), and the role of financial sector regulators needs to be revised in view of new challenges. Creation of Task Force on Climate-related Financial Disclosures (TCFD) or High Level Expert Group from the European Commision are good examples in this context.

According to the High Level Expert Group established by the European Commision, to reach the SDG only in EU it will need 180 billion euro annually, for which the European Fund for Strategic Investments has been created. However, the scale of investment challenges is beyond the capabilities of the public sector and requires the active involvement of financial sector institutions.

The inclusion of Ukraine in the SDG and the formation of a national system of their targets by 2030 will require a detailed analysis of the global experience in functioning of the CSR mechanism of the financial sector institutions and development of directions for its implementation.

The aim of this research is to study the significance of CSR mechanisms of financial sector institutions (for example, banks and stock exchanges) in implementation of investment opportunities for financing UN SDGs.

The role of CSRs of banks and stock exchanges as the largest players in the global financial sector aimed at overcoming investment barriers on the way to the SDG can be indicated as follows:

1) banks - ensuring their own sustainability and efficiency through CSR mechanisms with indirect influence on financial stability and achievement of sustainable development, formation of new tools, methods and technologies of financial support for SDG;

2) stock exchanges - minimization of information asymmetry in investor decision making, taking into account ESG criteria, formation of exemplary disclosure practices by listing companies in view of their progress in achieving the SDG and the specified criteria and monitoring the market environment for new SDG financial support instruments (green bonds).

The article is structured as follows: overview of normative sources on international and national level, scientific works in the field of regulation of CSR of financial sector institutions (Section 1); methods (Section 2); analysis of world experience in functioning of the CSR mechanism of the financial sector institutions in financing the SDG (Section 3); conclusions and perspectives for Ukraine. 


\section{LITERATURE REVIEW}

\subsection{Legal framework of the CSR mechanism of the financial sector institutions}

A thorough study of the concept of "corporate social responsibility" (CSR) has taken place since the beginning of the twentieth century. During this time, the concept of CSR has evolved substantially and has become widespread from isolated cases to systemic implementation in most areas of activity. There is no exception to the financial sector, where CSR has a significant impact on the strategy of financial institutions. The global financial crisis has shifted the emphasis on the strategy of the financial sector institutions to strengthen the responsibility for regulators and consumers of financial services; the adoption of the SDG - towards of increasing responsibility to all stakeholders.

At the international and national level, a number of normative documents and standards have been developed that regulate the functioning of the CSR mechanisms of the financial sector institutions. Among the key requirements that are common and cross-sectoral, one can refer to the 10 United Nations Global Compact Principles (UNGC) signed by most of the leading financial institutions. The International Standardization Organization proposes to use the ISO 26000 standard: 2010 "Social Responsibility Guideline", which discloses all aspects of the social responsibility of business entities in any field of activity, ranging from the interpretation of concepts, disclosure of the concept and key concept aspects, and ending with recommendations on the social responsibility implementation and examples of key successful practices. The following standards for disclosure and interaction with stakeholders are also widely used: GRI (Social Reporting Standard for a ThreeWay Sustainability Concept), AA1000 series (a set of recommendations and principles for preparing social reports based on dialog with stakeholders; key principles: comprehensive, substantive, and responsive). A series of standard certificates SA 8000 is intended for certification of organizations in labor relations.

Specific for the financial sector institutions are the United Nations-backed Principles for
Responsible Investment (PRI), Equator Principles, the Sustainability Stock Exchanges Initiative (SSEI), the United Nations Environment Program Finance Initiative (UNEP-FI), the United Nations Conference on Trade and Development (UNCTAD), the World Federation of Exchanges.

In particular, the last two organizations clearly define of the role of stock exchanges in ensuring sustainable development. According to the WFE experts, stock exchanges create information products and services for investors operating on the basis of the ESG criteria; implementing ESG standards among listed companies; forming specialized markets for specific sustainable investment niches WFE, 2010 Exchanges, ESG and Investment Decisions. A similar vision is presented in WFE and UNCTAD, 2017, The Role of Stock Exchanges in Fostering Economic Growth and Sustainable Development - The role of the stock exchanges in achieving sustainable development is first a supporting good governance in business practices and, second, investment in sustainable development.

At the national level, the CSR mechanisms of the financial sector institutions are detailed:

- at the level of legislative acts: the Financial Services Reform Act (Australia, 2010), Sustainable Development Act (Spain, 2010), Dodd-Frank Act, Investor Protection Act, Regulation S-K (USA, 2010);

- common documents: Environmental Risk Management (ERM). Guidelines for Banks and Financial Institutions (Bangladesh, 2011); Guidelines on Corporate Social Responsibility for Banking Financial Institutions (China, 2009), Code of Conduct (UK, 2010), Corporate Governance Code for Investors (Germany 2005);

- targeted (in favor of a certain group of institutions) documents: Code for Institutional Investors (Malaysia, 2014).

At the level of the European Commission, it is planned to amend certain Financial Directives (UCITS Directive 2009/65/EC, the AIFM Directive 2011/61/EU, the MiFID II Directive 2014/65/EU, 
the Solvency II Directive 2009/138/EC and the IDD Directive 2016/97) in the context of how asset management companies, insurance companies, investment or insurance advisors integrate into their organizational requirements, operational conditions and risk management sustainable development factors. Among other proposals within the framework of the EU Sustainable Development Financing Action Plan are:

1) development of the conceptual framework for the classification and taxonomy of activities, which can be classified as sustainable (environmentally sustainable economic activity);

2) suggestions for the regulation of disclosure about sustainable investments and sustainability risks to Directive (EU) 2016/2341, which include disclosure of information by financial institutions on their integration of the ESG criteria into the decision-making process;

3) suggestions for the development of comparative benchmarks for the carbon footprint of investments.

\subsection{CSR of financial sector institutions in the works of scholars}

The role of CSR for financial sector institutions is often analyzed geographically by scientists. The features of CSR in the financial sector of individual countries were studied by Khan (2009) concerning CSR banking sector of Bangladesh, Decker (2004) in terms of financial services in the UK, Tsang (1998)in Singapore, Branco (2006) - in Portuguese banks, Aribi (2010) - in Islamic world, Achua (2008) - in Nigerian banking system, Mirfazli (2008) - in public companies listed on the Indonesia Stock Exchange, LI Zheng (2006) - in Shanghai.

Within a species aspect in comparison with other financial sector institutions, in particular, stock exchange organizations, banks show weaker efforts in promoting initiatives and goals of sustainable development by means of CSR. The CSR mechanism used by them is mainly focused on the environmental dimension of sustainable development - resource and energy efficiency of banks.
At the same time, banks have a decisive role in the entire financial sector and in the economy as a whole (Khan \& Fasih, 2014). Despite the fact that in general, banks are organizations that are fully geared towards receiving and maximizing profits, the implementation of CSR measures has a positive impact not only on the reputation of a financial institution (Tran, 2014; Soana, 2011; Forcadell \& Aracil, 2017; Branco \& Rodrigues, 2006), but also on the financial performance and effectiveness of banks (San-José et al., 2011; Carnevale \& Mazzuca, 2014). Bank transparency as well as any other type of business is one of the main priorities that closely correlates with the concept of sustainable development and the achievement of its goals.

Along with the aforementioned, leading world experts and scientists use various economic and mathematical methods and models to assess the impact of the CSR mechanism on the activities of financial institutions and their indirect influence on the achievement of sustainable development. Such an influence is analyzed within the framework of three possible options for the establishment of relations: 1) the negative influence, based on the theory of corporate selfishness by Friedman (1970), which argues about the necessity to maximize profits; 2) the positive influence, based on significant achievements of leading scientists and specialists, as well as empirical research; 3) the neutral/the Missing Communication (Soana, 2011).

Many scientists have dedicated their research to the impact of CSR on various aspects of banking business. In particular, Scholtens (2009) declares a positive and significant link between CSR and financial performance, as well as the size of the bank, by analyzing socially responsible (ethics codes, CSR reports, environmental management, responsibility of financial products, social conduct) activity of 32 international banks of three major regions - Europe, North America and Asia Pacific. Banks, as financial intermediaries, significantly impact society while implementing their primary functions such as pricing and valuing financial assets, monitoring borrowers and managing financial risks (Scholtens, 2009).

The positive link between financial performance of banks (return on assets, return on equity, net 
interest income, and non-interest income) and CSR has been empirically confirmed by $\mathrm{Wu}$ and Shen (2013) for 162 banks from 22 countries.

An interesting study of the relationship between the social and financial components of the banks was conducted by Ahmed et al. (2012). At the first stage, a survey was conducted on the effectiveness of CSR measures in banks, according to which the researchers divided all the banks into socially active and socially-neutral. At the second stage, the financial status of banks - representatives of each group was analyzed and their effectiveness was determined (on the basis of ROA, ROE, EPS and $\mathrm{P} / \mathrm{E}$ ratio). As a result of the model construction, the following conclusions were made: socially active banks have better indicators of financial performance than socially-neutral ones.

The similar study was made by Paulík, Sobeková Majková, Tykva, and Červinka (2015) for the banking sector of the Czech Republic.

Broccardo, Costa, and Mazzuca (2017) investigated the impact of various CSR measures (economic, environmental and social) and approaches to the information disclosure about CSR on the financial performance of 88 Italian cooperative banks in the period 2007-2011. In the study, the links between CSR measures (including the scale and number of CSR activities) and the financial performance of Italian banks were not confirmed, while the volume of disclosed CSR information was argued to have a positive impact on the efficiency of banks. At the same time, the authors argue that it is necessary to take into consideration the limited sampling and the low level of quality assessment of CSR initiatives when interpreting their results.

A separate area for investigating the role of banks CSRs is the study of its impact on traditional banking operations and its business strategy (Jeucken \& Bouma, 1999), on the establishment of specific benchmarks for sustainable development, which create marks for this activity (Weber, 2005), its role in supporting financial stability (Nieto, 2017); directions of global regulation of sustainable development with the help of the largest banks of the world (Conley \& Williams, 2011) and central banks (Sheng, 2015).
In summary, most of the empirical studies on CSR impact on the activities of banks for financing sustainable development can be summarized in the following areas: 1) studying the impact of the implementation of CSR measures on the bank activities to change strategic orientations and constructing/transforming various business strategies (Calabrese \& Lancioni, 2008; Porter \& Kramer, 2006; Sen \& Bhattacharya, 2001); 2) analysis of the relationship between CSR and the financial performance of banks (Soana, 2011; Scholtens, 2009; Wu \& Shen, 2013; Ahmed et al., 2012; Paulík et al., 2015; Broccardo et al., 2017); 3) the impact of CSR on relations with stakeholders (Bhattacharya et al., 2009; Jones, 1995; Sharma \& Vredenburg, 1998; Dam \& Scholtens, 2012), 4) the impact of the CSR mechanism on the bank financing of investment in sustainable development (Sheng, 2015; Weber, 2005; Nieto, 2017; Conley \& Williams, 2011).

The study of the role of exchanges as the largest intermediary organizations, which are shaping the market environment for the realization of investment opportunities for sustainable development in the researches of scientists is presented less widely than banking institutions. The analyzed works can be grouped as:

- studying the importance of stock exchanges in overcoming market externalities, raising transparency and disclosing information relative to the ESG criteria for making more informed investment decisions (Myklebust, 2013), assessing the value of exchanges in supporting the initiatives of Sustainable Development with the Sustainability Support Index (Kalinowski, 2014), ensuring an adequate level of corporate governance (Hans \& Amico, 2009);

theroleof exchangesinensuring theeffectiveness of market transformations, market convergence (Szulc et al., 2014), to ensure economic growth and the flow of foreign capital (Raza \& Jawaid, 2014), prospects for the development of a stock environment in developing countries, taking into consideration the challenges of sustainable development (Claessens et al., 2002). 
Thus, among scientific sources, the priority is the study of banks' impact on sustainable development in the context of their own efficiency and maintaining financial sustainability through CSR mechanisms, taking into consideration new investment opportunities and their peculiarities in the strategy and tactics of financial institutions activities; while the impact of stock exchanges is analyzed through the creation of best market practices and opportunities for investment decisions based on ESG criteria. However, it should be noted that most of the papers analyzed do not consider the role of CSR of financial sector institutions after the adoption of the SDGs in 2015, which requires a separate study.

\section{METHODS}

The concepts of sustainability, corporate social responsibility and corporate governance as well as stakeholder theory have made theoretical and methodological basis of the study.

Stakeholder theory is a key point in investigating the CSR mechanism for the financial sector institutions because of specific information expectations and requests of such institution key stakeholders. These requests determined the directions of the CSR mechanism realization, varied significantly under sustainability and observed related to each SDG, specific to banks and stock exchanges.

\section{RESULTS AND DISCUSSION}

The peculiarities of the CSR mechanism implementation in the financial sector are primarily determined by the information expectations and requests of their key stakeholders, which are specific to the sector. Among the main stakeholders of the financial sector institutions, it is advisable to highlight the following: external (clients, central banks, other financial regulators, other banks, unions, non-profit organizations, public authorities) and internal (shareholders, managers, staff). Responsiveness and accountability in its CSR strategy and the disclosure of information about the most significant requests of these stakeholders are the basis for an effective dialog and the CSR mechanism functioning. At the same time, traditional expectations of stakeholders regarding responsible behavior of banks and exchanges are significantly changing in the context of the adoption of 17 SDGs of UN, which are identified in 169 targets.

Investigation of the most significant requests and expectations of stakeholders in financial sector institutions was made by the Global Reporting Initiative (GRI, 2013), which identified more than 2,800 thematic areas in 52 sectors of the economy. 834 recommended indicators for the most significant stakeholders requests on progress in the achievement of the SDGs by various institutions, including the financial sector, were determined by the GRI, the UN Global Compact and the World Business Council on Sustainable Development (GRI, 2016).

In addition, the definition of the most relevant SDGs for CSR activities in financial institutions, in particular banks and exchanges, remains a controversial issue.

The analysis of the two named documents of GRI allowed to select the priority goals for financial institutions with their gradation into two categories: SDGs, which are inherent for the internal activities of such institutions, and SDGs, which are related to the provision of financial services and the sale of financial products (Tables 1 and 2).

Thus, SDGS 5 and 12 are the most relevant for the operational practices of banks and exchanges; SDGs 1, 5, 8, 10, 13, 17 for financing of sustainable development. Incorporation of these goals into activities of the financial sector institutions not only requires the activation of their CSR mechanism in the directions indicated by the targets, but also the radical restructuring of all business processes and the reorientation of their overall strategy in the context of sustainable development.

In view of this, the priority areas for the implementation of CSR mechanism of banking institutions aimed at achieving the goals related to the provision of financial services and the sale of financial products, are as follows: 
Table 1. The most relevant SDGs related to the provision of financial services and the sale of financial products and their impact on the CSR mechanism

\begin{tabular}{|c|c|c|c|}
\hline Goal & Target & Stakeholders request & $\begin{array}{l}\text { Impact on the CSR } \\
\text { mechanism }\end{array}$ \\
\hline \multirow{2}{*}{$\begin{array}{l}1 \text { End poverty in all } \\
\text { its forms everywhere }\end{array}$} & \multirow{2}{*}{$\begin{array}{l}\text { 1.4 By 2030, ensure that all men and } \\
\text { women, in particular the poor and } \\
\text { the vulnerable, have equal rights } \\
\text { to economic resources, as well as } \\
\text { access to basic services, ownership } \\
\text { and control over land and other } \\
\text { forms of property, inheritance, natural } \\
\text { resources, appropriate new technology } \\
\text { and financial services, including } \\
\text { microfinance }\end{array}$} & $\begin{array}{l}\text { Access to financial resources } \\
\text { and services }\end{array}$ & $\begin{array}{l}\text { Influence on the development } \\
\text { of initiatives on financing } \\
\text { of small and medium } \\
\text { enterprises, financial literacy } \\
\text { of the population }\end{array}$ \\
\hline & & $\begin{array}{l}\text { Protection of the rights of } \\
\text { consumers of financial services }\end{array}$ & Accountability to consumers \\
\hline \multirow[b]{2}{*}{$\begin{array}{l}8 \text { Promote inclusive } \\
\text { and sustainable } \\
\text { economic growth, } \\
\text { employment and } \\
\text { decent work for all }\end{array}$} & \multirow[b]{2}{*}{$\begin{array}{l}\text { 8.1 Sustain per capita economic } \\
\text { growth in accordance with national } \\
\text { circumstances and, in particular, at } \\
\text { least } 7 \text { per cent gross domestic product } \\
\text { growth per annum in the least developed } \\
\text { countries }\end{array}$} & Community investments & \multirow[b]{2}{*}{$\begin{array}{l}\text { Demonstrates the role of } \\
\text { the institution in ensuring } \\
\text { development at the } \\
\text { local level, taking into } \\
\text { consideration community } \\
\text { requests and implementing } \\
\text { the investment strategy, taking } \\
\text { into consideration the ESG } \\
\text { criteria }\end{array}$} \\
\hline & & Responsible investing & \\
\hline $\begin{array}{l}10 \text { Reduce } \\
\text { inequality within } \\
\text { and among countries }\end{array}$ & $\begin{array}{l}10.5 \text { Improve the regulation and } \\
\text { monitoring of global financial markets } \\
\text { and institutions and strengthen the } \\
\text { implementation of such regulations }\end{array}$ & Stability of the financial sector & $\begin{array}{l}\text { Taking into consideration the } \\
\text { impact of the systemic risks } \\
\text { of large banks and exchanges, } \\
\text { "too big too fall", ensuring the } \\
\text { solvency and accountability } \\
\text { of financial institutions to } \\
\text { regulators of different levels } \\
\text { and to the public }\end{array}$ \\
\hline $\begin{array}{l}13 \text { Take urgent } \\
\text { action to combat } \\
\text { climate change and } \\
\text { its impacts }\end{array}$ & $\begin{array}{l}13.1 \text { Strengthen resilience and adaptive } \\
\text { capacity to climate-related hazards and } \\
\text { natural disasters in all countries. } \\
13.2 \text { Improve education, awareness } \\
\text { raising and human and institutional } \\
\text { capacity on climate change mitigation, } \\
\text { adaptation, impact reduction, and early } \\
\text { warning }\end{array}$ & $\begin{array}{l}\text { Environmental and social } \\
\text { impacts of financial products, } \\
\text { investments and services, } \\
\text { support of national sustainable } \\
\text { development policies (banks, } \\
\text { stock exchanges), creation } \\
\text { of new markets for financial } \\
\text { products aimed at supporting } \\
\text { sustainable development (stock } \\
\text { exchanges) }\end{array}$ & $\begin{array}{l}\text { Influence of ESG criteria and } \\
\text { consequences of climate } \\
\text { change on risk assessment } \\
\text { and CSR strategy, business } \\
\text { strategy, accountability to } \\
\text { shareholders }\end{array}$ \\
\hline $\begin{array}{l}17 \text { Revitalize the } \\
\text { global partnership } \\
\text { for sustainable } \\
\text { development }\end{array}$ & $\begin{array}{l}\text { 17.16 Enhance the global partnership for } \\
\text { sustainable development complemented } \\
\text { by multi-stakeholder partnerships } \\
\text { that mobilize and share knowledge, } \\
\text { expertise, technologies and financial } \\
\text { resources to support the achievement } \\
\text { of sustainable development goals in all } \\
\text { countries, particularly developing ones }\end{array}$ & $\begin{array}{l}\text { Creating partnerships and } \\
\text { networks, sharing experiences, } \\
\text { knowledge and resources }\end{array}$ & $\begin{array}{l}\text { Establishing effective } \\
\text { communications within the } \\
\text { partnership of stakeholders to } \\
\text { achieve the SDGs }\end{array}$ \\
\hline
\end{tabular}

Table 2. The most relevant SDGs, which are inherent in the internal activities of such institutions and their impact on the CSR mechanism

\begin{tabular}{|c|c|c|c|}
\hline Goal & Target & Stakeholders request & $\begin{array}{l}\text { Impact on the CSR } \\
\text { mechanism }\end{array}$ \\
\hline \multirow{2}{*}{5 Gender equality } & \multirow{2}{*}{$\begin{array}{l}5.5 \text { Ensure women's full and effective } \\
\text { participation and equal opportunities } \\
\text { for leadership at all levels of decision- } \\
\text { making in political, economic, and } \\
\text { public life }\end{array}$} & $\begin{array}{l}\text { Promotion of gender diversity } \\
\text { at the level of government } \\
\text { institutions }\end{array}$ & \multirow{2}{*}{$\begin{array}{l}\text { Influence of CSR activities } \\
\text { in the context of ensuring } \\
\text { accountability to consumers } \\
\text { and management }\end{array}$} \\
\hline & & $\begin{array}{l}\text { Ensure equal access of women } \\
\text { and girls to financial products } \\
\text { and services }\end{array}$ & \\
\hline \multirow[b]{2}{*}{$\begin{array}{l}12 \text { Responsible } \\
\text { consumption and } \\
\text { production }\end{array}$} & \multirow{2}{*}{$\begin{array}{l}12.6 \text { Encourage companies, especially } \\
\text { large and transnational ones, to adopt } \\
\text { sustainable practices and to integrate } \\
\text { sustainability information into their } \\
\text { reporting cycle }\end{array}$} & $\begin{array}{l}\text { Disclosure of complete and } \\
\text { reliable information on progress } \\
\text { in achieving the SDGs }\end{array}$ & $\begin{array}{l}\text { Own information } \\
\text { transparency and dialog with } \\
\text { stakeholders (all groups) } \\
\text { within CSR activities }\end{array}$ \\
\hline & & $\begin{array}{l}\text { Formation of market } \\
\text { benchmarks (indices of } \\
\text { sustainable development) and } \\
\text { requirements for disclosure of } \\
\text { information by listed companies } \\
\text { (exchanges), borrowers (banks) }\end{array}$ & $\begin{array}{l}\text { Promoting transparency } \\
\text { among customers }\end{array}$ \\
\hline
\end{tabular}


- facilitating financial literacy and awareness, financial education, shaping an information field for the stakeholders interaction;

- providing transparent and equitable financial products and services, establishing specific conditions for their provision to low-income individuals, and micro-credit conditions for people with disabilities (for individuals); creating favorable lending regime for small and medium enterprises taking the ESG criteria into account;

- formation of lending standards for a wide range of clients, taking into consideration ESG criteria and principles for responsible investment, promotion of green and energy efficient loans.

These areas of CSR influence are primarily specific to the financial activities of banking institutions and create additional benefits and positive effects on their financial and economic efficiency, as indicated in a number of research studies. Among these areas, the International Finance Corporation mentions a reducting the cost of raising capital, raising the value of the banking brand, rating of the banks solvency and improving the conditions for the bank risk insurance.

If these priority directions of the SDGs achievement are common to banks and stock exchanges, the directions of achieving the goals, which are inherent in the internal activities of financial institutions, in particular the increase of transparency and coverage of CSR, are somewhat different.

Reporting on sustainable development by banking institutions is purely reputational, personalized, and the reports themselves are addressed to a certain stakeholder group or reveal progress in reaching certain SDGs by the bank.

At the same time, stock exchanges use reporting on sustainable development, the formation of market benchmarks and sustainable development indices, primarily for the establishment of listing conditions for issuers, and not only for the coverage of their own activities.

The consolidation of these CSR exposure guidelines for stock exchanges for sustainable development fi- nancing in 2009 was developed in the form of SSEI, created by UNCTAD, the UN Global Compact, UNEP Financial Initiative and UN Principles for Responsible Investment (PRI). At the end of 2017, this initiative includes 65 leading exchanges in the world, 38 of which have created ESG indices (about 100 indices of sustainable development - the most well-known Dow Jones Sustainability Index), 32 provide guidance on taking into consideration ESG criteria for bidders, 18 - conducting trainings to strengthen the quality of corporate governance, incorporation of social and environmental criteria into the activities of listing companies, 12 - to take into account ESG criteria in the listing rules (Hong Kong Stock Exchange, Singapore Stock Exchange), 11 provide support for the listing of green bonds (the nominal value of which is constantly growing and in early 2017 it was USD 180 billion).

Despite the scale of the transformation of CSR and business activities that must be conducted by institutions in the financial sector for the sustainable development, taking into consideration mentioned innovations, the number of these companies is steadily increasing every year (Figure 1). The disclosure of CSR information and the transparency of the institutions activities are an important aspect of their CSR mechanism functioning. According to GRI in 2016, the number of non-financial reports (reports on sustainable development) of banks, stock exchanges, asset management companies and other financial sector entities amounted to 970 globally. This is almost 162 times more than in 2000, when the first six financial institutions have posted similar reports.

The number of financial sector reporting entities that implement sustainable development values in their activities and the CSR mechanism is steadily increasing from year to year, showing an annual average growth rate of $34.4 \%$. This indicates a steady increase in the number of institutions, which are seeking to increase their transparency regarding progress in achieving the Millennium Development Goals (2015) and SDGs (after their adoption in 2015).

At the same time, the most significant increase in the number of reporting financial institutions by $46.0 \%$ - was observed not after 2015 , but in 2010-2011. 


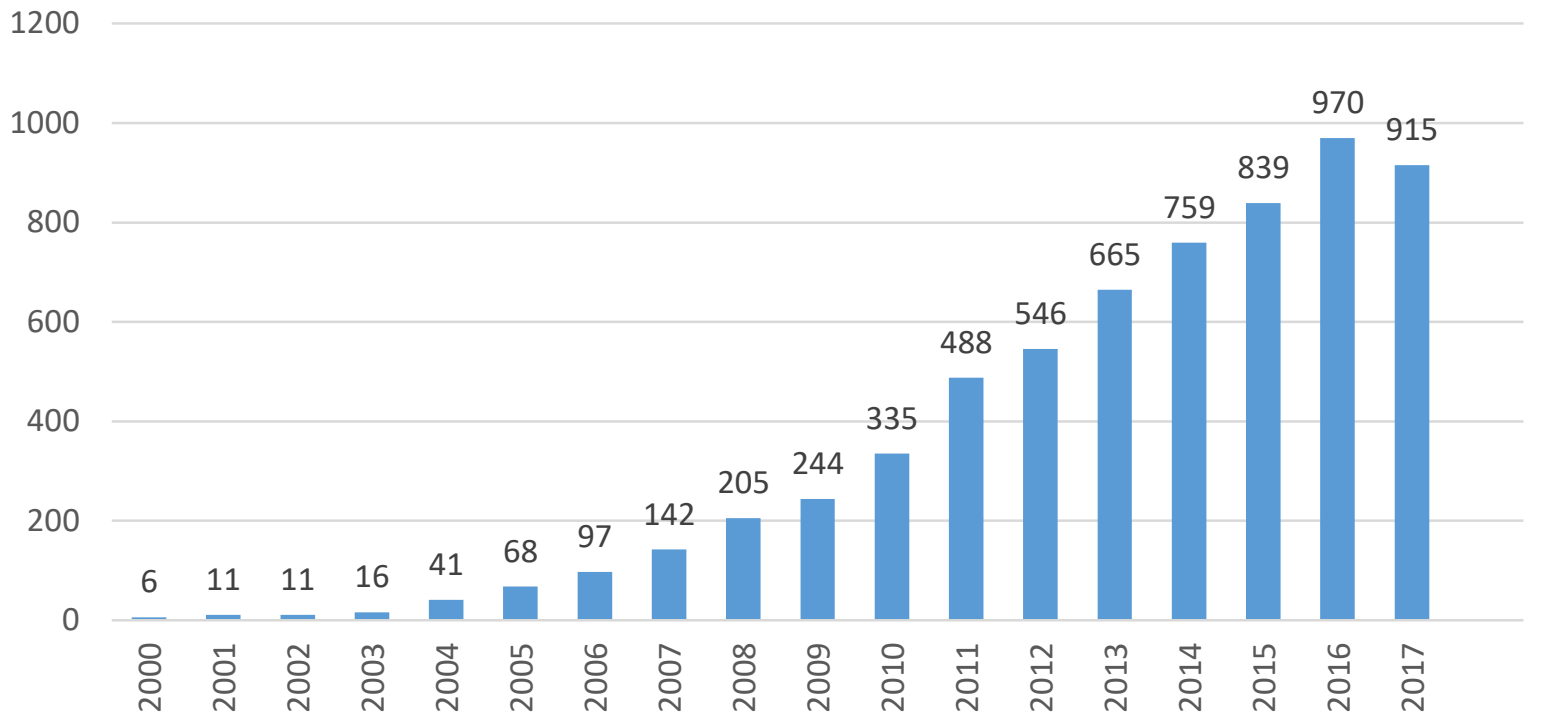

Figure 1. The number of reports on the sustainable development of financial sector institutions in 2000-2017 according to GRI, units

The reasons for such a dynamics of the number of reports can be:

1) restructuring old activity according to the SDGs and its disclosure in the reports on sustainable development has a certain lag;

2) the intensification of efforts by financial sector entities in reporting on sustainable development after the global 2007-2009 financial crisis is explained by the emergence of more stringent regulatory requirements for the transparency and disclosure of information by such institutions and the formation of new, more competitive strategies;

3) some reduction in the number of reports on the sustainable development of financial sector institutions (by 5.7\%) in 2017 is due to a certain time lag in publishing such reports, as well as a possible two-year reporting cycle of institutions.

In addition to the dynamics analysis, the analysis of the regional cut of the number of sustainable development reports submitted by the financial sector institutions in 2000-2017 allows us to confirm the upward trend of this indicator in all six regions of the world.
Table 3. The number of reports on sustainable development submitted by financial sector institutions in 2000-2017, units

Source: Authors' development on the basis of GRI SDD Database (2017).

\begin{tabular}{|c|c|c|c|c|c|c|}
\hline$\underset{\mathbb{J}}{\grave{ঠ}}$ & $\frac{\text { 은 }}{\frac{1}{2}}$ & $\frac{\pi}{\frac{\pi}{2}}$ & 送 & 들 & 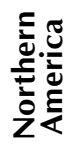 & 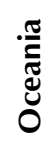 \\
\hline 2000 & 0 & 2 & 2 & 1 & 1 & 0 \\
\hline 2001 & 0 & 1 & 8 & 1 & 1 & 0 \\
\hline 2002 & 0 & 2 & 5 & 1 & 1 & 2 \\
\hline 2003 & 3 & 1 & 7 & 1 & 3 & 1 \\
\hline 2004 & 8 & 1 & 21 & 2 & 5 & 4 \\
\hline 2005 & 8 & 2 & 42 & 4 & 6 & 6 \\
\hline 2006 & 9 & 6 & 56 & 7 & 10 & 9 \\
\hline 2007 & 6 & 20 & 82 & 13 & 13 & 8 \\
\hline 2008 & 14 & 31 & 111 & 20 & 21 & 8 \\
\hline 2009 & 14 & 47 & 123 & 30 & 20 & 10 \\
\hline 2010 & 16 & 68 & 160 & 52 & 26 & 13 \\
\hline 2011 & 64 & 105 & 193 & 68 & 45 & 13 \\
\hline 2012 & 48 & 128 & 209 & 93 & 52 & 16 \\
\hline 2013 & 54 & 166 & 248 & 113 & 63 & 21 \\
\hline 2014 & 55 & 212 & 284 & 121 & 63 & 24 \\
\hline 2015 & 55 & 247 & 297 & 148 & 68 & 24 \\
\hline 2016 & 112 & 291 & 324 & 144 & 72 & 27 \\
\hline 2017 & 133 & 325 & 272 & 137 & 42 & 6 \\
\hline
\end{tabular}

In particular, the significant increase in the number of reporting entities in the African region in 2011 was due to the Johannesburg Stock Exchanges' (SA) adoption of a compulsory submission of the 
Sustainability Report (Integrated Report) by listing companies. Significant recovery in reporting by financial institutions in the Asian region in 2011 and 2013-2014 were caused by the adoption of the Guidelines for Banks and Financial Institutions (Bangladesh, 2011); Guidelines on Corporate Social Responsibility for Banking Financial Institutions (China, 2009), Code for Institutional Investors (Malaysia, 2014). These documents also substantially increase the transparency requirements of CSR-activities of financial sector institutions. The institutions of the financial sector in Europe showed an increase in the publication activity of the Sustainable Development Reports in 2011-2012 and in 2014-2016, which is due to the update of the EU CSR Strategy for 2011-2014. The following documents communication from the Commission to the European Parliament, the Council, the European Economic and Social Committee and the Committee of the Regions, a Renewed EU Strategy 2011-2014 for Corporate Social Responsibility, as well as the adoption of Directive 2014/95/EU, considerably expand the list of reporting agencies, including public interest entities, which include banks and exchanges.

Among other regions, the most significant growth of financial sector reporting in North America was observed in 2011, in view of the large-scale reform of the financial sector in response to the effects of the mortgage and global financial crisis (DoddFrank Act, Investor Protection Act, Regulation S-K (USA, 2010)).

In Ukraine, disclosing information about CSR activity is only beginning to form. During 2000-2017, two banks (PlatinumBank and Unikreditbank) issued only 9 reports on sustainable development. At the National Bank of Ukraine level, the issues of introduction and regulation of CSR mechanisms in the banking system of Ukraine from 2014 are at the level of consultations. In particular, the National Bank of Ukraine offered to banks to consider the possibility of revision of payment terms for obligations under loan agreements, which are concluded with persons called for military service, namely, the possibility of developing programs for assistance in repayment of principal payment and payment of interest, non-payment of penalties for late execution debt. The organizers of stock trading on the stock market of Ukraine still stand aside initiatives to finance sustainable development, primarily because of its depressive state. None of the Ukrainian stock exchanges has yet joined the SSEI.

\section{CONCLUSION}

The necessity to attract significant financial resources to finance the SDGs as well as to overcome the effects of climate change requires rethinking the role of institutions in the financial sector and their CSR mechanisms and ensuring the integration of ESG criteria into the practice of making investment decisions in the financial sector, taking into account new investment opportunities and developing new investment products, overcoming information asymmetry between participants in the investment process.

This role lies within a broad legal framework, which includes both internationally recognized cross-sectoral and specific for financial sector and recommendations on CSR, as well as national regulatory documents. Most of the documents were adopted to overcome the effects of the global financial crisis and ensure the financial sector sustainability.

The study of banks influence on sustainable development in the context of their own efficiency and maintaining financial sustainability through CSR mechanisms, prevails in academic spheres. The impact of CSR of exchanges is seen by academics in the context of creating an environment for investment decisions, which is based on ESG criteria.

Systematization of world experience in implementing the CSR mechanism by the financial sector institutions has made it possible to identify the following key areas of its impact on financing the most relevant SDGs and their targets $(1,5,8,10,12,13,17)$ as: ensuring sustainability and efficiency through 
CSR mechanisms with mediated influence on financial stability and achievement of sustainable development, formation of new tools, methods and technologies of financial support of SDGs - mainly it is a bank; minimizing information asymmetry in decision-making by investors, taking into consideration ESG criteria, forming exemplary practices of disclosure by listing companies and market benchmarks mostly it is a stock exchange.

At the same time, the specified SDGs, taking into account the key requests of stakeholders of financial sector institutions and their impact on the CSR mechanism can be adjusted as follows: SDGs, which are inherent in the internal activities of such institutions, and SDGs, which are related to the provision of financial services and the sale of financial products.

The incorporation of these SDGs into the activities of the financial sector institutions requires a radical restructuring of all business processes and the reorientation of their overall strategy in the context of sustainable development. However, such large-scale tasks at the same time do not stop financial institutions. Their number, on the basis of published reports on sustainable development, grows by an average of one-third in both by years and in the regional context. Some significant growth in the reports on sustainable development in the regions of the world is due to institutional reforms of the banking system or the exchange sector of one or another country.

Ukraine does not have systematic measures to promote the development of CSR in the financial sector, which does not allow its potential to be used to finance national tasks to achieve the Sustainable Development Goals.

\section{ACKNOWLEDGEMENT}

Comments from the Editor and anonymous referees have been gratefully acknowledged. Inna Makarenko gratefully acknowledges financial support from the Ministry of Education and Science of Ukraine "Corporate social and environmental responsibility for sustainable development: stakeholders partnership in the real, financial and public sectors of the economy" (0117U003933).

\section{REFERENCES}

1. Ahmed, S. U., Islam, M. Z., \& Hasan, I. (2012). Corporate Social Responsibility and Financial Performance Linkage - Evidence from the Banking Sector of Bangladesh. Journal of Organizational Management, 1, 14-21. Retrieved from https://www.researchgate. net/publication/228273307_Corporate_Social_Responsibility_and_ Financial_Performance_Linkage_Evidence_from_the_Banking_Sector_of_Bangladesh

2. Aribi, Z. A. (2010). Corporate social responsibility disclosure: A comparison between Islamic and conventional financial institutions. Journal of Financial Reporting and Accounting, 8(2), 72-91. https://doi. org/10.1108/19852511011088352
3. Bhattacharya, C. B., Korschun, D., \& Sen, S. (2009). Strengthening Stakeholder-Company Relationships Through Mutually Beneficial Corporate Social Responsibility Initiatives. Journal of Business Ethics, 85(2), 257-272. https://doi. org/10.1007/s10551-008-9730-3

4. Branco, M. C. (2006). Communication of corporate social responsibility by Portuguese banks: A legitimacy theory perspective. Corporate Communications: An International Journal, 11(3), 232-248. https://doi. org/10.1108/13563280610680821

5. Branco, M.C., \& Rodrigues, L. L. (2006). Corporate Social Responsibility and Resource-Based Perspectives, Journal of Business
Ethics, 69(2), 111-132. Retrieved from https://www.researchgate. net/publication/227234865_Corporate_Social_Responsibility_and_ Resource-Based_Perspectives

6. Broccardo, E., Costa, E., \& Mazzuca, M. (2017). Corporate Social Responsibility and Financial Performance in Italian Co-operative Banks, Routledge handbook of social and sustainable finance (pp. 280-295). London: Routledge. https://doi. org/10.4324/9781315772578

7. Calabrese, A., \& Lancioni, F. (2008). Analysis of Corporate Social Responsibility in the Service Sector: Does Exist a strategic Path? Knowledge and Process Management, 15(2), 107-125. https:// doi.org $/ 10.1002 / \mathrm{kpm} .303$ 
8. Carnevale, C., \& Mazzuca, M. (2014). Sustainability Report and Bank Valuation: Evidence from European Stock Markets. Business Ethics: A European Review, 23(1); 69-90. https://doi.org/10.1111/ beer.12038

9. Chih H. L., Chih H. H., \& Chen T. (2010). On the Determinants of Corporate Social Responsibility: International Evidence on the Financial Industry. Journal of Business Ethics, 93(1), 115-135. https://doi.org/10.1007/s10551009-0186-x

10. Christiansen, Hans, \& Amico (Koldertsova), Alissa (2009 January 23). The Role of Stock Exchanges in Corporate Governance (OECD Working Paper No. 2009/1). Retrieved from https://ssrn.com/

11. Claessens, S., Klingebiel, D., \& Schmukler, S. L. (2002). The Future of Stock Exchanges in Emerging Economies: Evolution and Prospects (pp. 167-212). (Brookings-Wharton Papers on Financial Services 2002(1). Brookings Institution Press. Retrieved from Project MUSE database, January 9, 2018. https:// doi.org/10.1353/pfs.2002.0007

12. Code for Institutional Investors (Malaysia, 2014). Retrieved from https://www.sc.com.my/wpcontent/uploads/eng/html/cg/ mcii_140627.pdf

13. Code of Conduct (UK, 2010) Retrieved from https://publications.parliament.uk/pa/cm201012/ cmcode/1885/1885.pdf

14. Communication from the Commission to the European Parliament, the Council, the European Economic and Social Committee and the Committee of the regions a renewed EU Strategy 2011-14 for CSR. Retrieved from https://eur-lex. europa.eu/legal-content/EN/TX $\mathrm{T} /$ ?uri=celex\%3A52011DC0681

15. Conley, J. M., \& Williams, C. A. (2011). Global Banks as Global Sustainability Regulators? The Equator Principles. Law \& Policy, 33(4), 449-602. https://doi.org/10.1111/j.14679930.2011.00348.x
16. Corporate Governance Code for Investors (Germany, 2005). Retrieved from http://www.ecgi.org/ codes/documents/code_200506_ de.pdf

17. Dam, L., \& Scholtens, B. (2012). Does Ownership Type Matter for Corporate Social Responsibility? Corporate Governance: an International Review, 20(3), 233-52. https://doi.org/10.1111/j.14678683.2011.00907.x

18. Decker, O. S. (2004). Corporate social responsibility and structural change in financial services. Managerial Auditing Journal, 19(6) 712-728. https://doi. org/10.1108/02686900410543840

19. Directive 2014/95/EU. Retrieved from https://eur-lex.europa.eu/ legal-content/EN/TXT/PDF/?uri= CELEX:32014L0095\&from=FI

20. Dodd-Frank Act (2010). Retrieved from https://www.gpo.gov/fdsys/ pkg/PLAW-111publ203/pdf/ PLAW-111publ203.pdf

21. Forcadell, F. J., \& Aracil, E. (2017). European Banks' Reputation for Corporate Social Responsibility. Corporate Social Responsibility and Environmental Management, 24, 1-14. https://doi.org/10.1002/ csr. 1402

22. Friedman, M. (1970). The Social Responsibility of Business is to Increase its Profits. New York Times Magazine, September 13, 211-214.

23. GRI SDD Database (2017). Retrieved from http://database. globalreporting.org/search

24. Guidelines for Banks and Financial Institutions (Bangladesh, 2011). Retrieved from https://www.bb.org. bd/aboutus/regulationguideline/ jan302011erm.pdf

25. How banks can help to Sustainable finance (n. d.). Retrieved from https://www.bbva.com/en/bankscan-help-sustainable-finance/

26. Interim report on sustainable finance (n. d.). Retrieved from https://ec.europa.eu/info/ publications/170713-sustainablefinance-report_en

27. International Finance Corporation (n. d.). Retrieved from https://www.ifc.org/wps/wcm/ connect/d7358880423f97ddb616be0dc33b630b/sustFinance. pdf?MOD=AJPERES

28. Jeucken, M., \& Bouma, J. (1999) The Changing Environment of Banks. Greener Management International, 27, 21. Academic Search Premier, EBSCOhost. http://dx.doi.org/10.9774/ GLEAF.3062.1999.au.00005

29. Jones, T. M. (1995). Instrumental Stakeholder Theory: a Synthesis of Ethics and Economics. Academy of Management Review, 20(2), 404-437. http://dx.doi. org/10.2307/258852

30. Joseph K. Achua. (2008). Corporate social responsibility in Nigerian banking system. Society and Business Review, 3(1), 57-71. https://doi. org/10.1108/17465680810852748

31. Kalinowski, M. (2014). Stock Exchanges Sustainability Support Assessment. Copernican Journal of Finance \& Accounting, 3(2), 37-48. http://dx.doi.org/10.12775/ CJFA.2014.016

32. Khan, M. Habib-Uz-Zaman. (2009). Corporate social responsibility (CSR) reporting: a study of selected banking companies in Bangladesh. Social Responsibility Journal, 5(3), 344-357. https://doi. org/10.1108/17471110910977276

33. Khan, M. M., \& Fasih, M. (2014). Impact of Service Quality on Customer Satisfaction and Customer Loyalty: Evidence from Banking Sector, Pakistan. Journal of Commerce and Social Sciences, 8(2), 331-354. Retreived from https://www.researchgate.net/ publication/280314174_Impact_ of_Service_Quality_on_Customer_Satisfaction_of_Banking_Sector_Employees_A_Study_of_Lahore_Punjab

34. Mirfazli, E. (2008). Corporate social responsibility (CSR) information disclosure by annual reports of public companies listed at Indonesia Stock Exchange (IDX). International Journal of Islamic and Middle Eastern Finance and Management, 1(4), 275-284. https://doi. org/10.1108/17538390810919592 
35. Myklebust, T. (2013, September 12). The Role of Stock Exchanges in Shaping More Sustainable Company and Market Practices (University of Oslo Faculty of Law Research Paper No. 2013-28; Nordic \& European Company Law Working Paper No. 10-41). Retrieved from https://ssrn.com/ abstract $=2324743$

36. Nieto, M. J. (2017). Banks and Environmental Sustainability: Some reflections from the perspective of financial stability. CEPS Policy Brief, 2017/01. Retrieved from http://aei.pitt.edu/86830/1/ PBNo_2017-01_MNieto_BanksEnvironmentalSustainability.pdf

37. Paulík, J., Sobeková Majková, M., Tykva, T., \& Červinka, M. (2015). Application of the CSR Measuring Model in Commercial Bank in Relation to their Financial Performance. Economics and Sociology, 8(4), 65-81. https://doi.org/10.14254/2071789X.2015/8-4/5

38. Porter, M., \& Kramer, M. (2006). Strategy and Society: The Link Between Competitive Advantage and Corporate Social Responsibility. Harvard Business Review, 84(12), 78-92. Retreived from https://hbr. org/2006/12/strategy-and-societythe-link-between-competitiveadvantage-and-corporate-socialresponsibility

39. Press Release Bankers and Government representatives discussed the urgent tasks of the banking system. Retrieved from https:// bank.gov.ua/control/uk/publish/ article?art_id=7841198

40. Raza, S. A., \& Jawaid, S. T. (2014, January). Foreign capital inflows, economic growth and stock market capitalization in Asian countries: an ARDL bound testing approach. Quality \& Quantity, 48(1), 375-385. https://doi. org/10.1007/s11135-012-9774-4

41. San-José, L., Retolaza, J., \& Gutiérrez-Goiria, J. (2011). Are Ethical Banks Different? A Comparative Analysis Using the Radical Affinity Index. Journal of Business Ethics, 100(1), 151-173. https://doi. org/10.1007/s10551-011-0774-4
42. Scholtens, B. (2009). Corporate Social Responsibility in the International Banking Industry. Journal of Business Ethics, 86(2), 159-175. https://doi.org/10.1007/s10551008-9841-x

43. SDG Compass Guide Ukranian. Retrieved from https://sdgcompass.org/wp-content/uploads/2016/09/SDG_Compass_ Guide_Ukranian.pdf

44. SDGs UN 2030 Agenda and Sustainable Development Goals. Retrieved from https://sustainabledevelopment.un.org/post2015/ transformingourworld

45. Sen, S., \& Bhattacharya, C. (2001). Does Doing Good Always Lead to Doing Better? Consumer Reactions to Corporate Social Responsibility. Journal of Marketing Research, 38(2), 225-243. https://doi. org/10.1509/jmkr.38.2.225.18838

46. Sharma, S., \& Vredenburg, H. (1998). Proactive Corporate Environmental Strategy and the Development of Competitively Valuable Organizational Capabilities. Strategic Management Journal, 19(8), 729-753. https:// doi.org/10.1002/(SICI)10970266(199808)19:8\%3C729::AIDSMJ967\%3E3.0.CO;2-4

47. Soana, M. G. (2011). The Relationship Between Corporate Social Performance and Corporate Financial Performance in the Banking Sector. Journal of Business Ethics, 104(1), 133-148. https://doi. org/10.1007/s10551-011-0894-X

48. SSE. (2015). Sustainable Development Goals. What do they mean for stock exchanges? SSE Leaders Luncheon 24 September 2015. Retrieved from http://www. sseinitiative.org/wp-content/uploads/2015/09/SDGs.pdf

49. SSE Executive Dialogue on Green Finance. UNCTAD World Investment Forum. 20 July 2015. Retrieved from http://www. sseinitiative.org/wp-content/ uploads/2016/07/Green-FinancePolicy-Brief.pdf

50. Sustainable Development Goals for Stock Exchanges. Retrieved from www.SSEinitiative.org/SDGs
51. Sustainable finance. (2018). Retrieved from https://ec.europa. eu/info/business-economy-euro/ banking-and-finance/sustainablefinance_en

52. Szulc, E. et al. (2014). The Significance of Distance Between Stock Exchanges Undergoing the Process of Convergence: an Analysis of Selected World Stock Exchanges During the Period of 2004-2012. Dynamic Econometric Models, Uniwersytet Mikolaja Kopernika, 14, 125 144. http://dx.doi.org/10.12775/ DEM.2014.007

53. The Financial Services Reform Act of Australia (2001). Retrieved from https://www.legislation.gov. au/Details/C2004C01201

54. Tran, Yen Thi Hoang, (2014). CSR in Banking Sector: a Literature Review and New Research Directions. International Journal of Economics, Commerce and Management, 2(11). Retrieved from http://ijecm.co.uk/wp-content/uploads/2014/11/21112.pdf

55. Tsang, E. W. K. (1998). A longitudinal study of corporate social reporting in Singapore: The case of the banking, food and beverages and hotel industries. Accounting, Auditing \& Accountability Journal, 11(5), 624-635. https://doi. org/10.1108/09513579810239873

56. UNCTAD (2014). World Investment Report. Retrieved from http://unctad. org/en/pages/PressRelease. aspx? OriginalVersionID $=194$

57. Weber, O. (2005). Sustainability benchmarking of European banks and financial service organizations. Corporate Social Responsibility and Environmental Management, 12(2), 73-87. https://doi.org/10.1002/csr.77

58. WFE and UNCTAD. (2017). The Role of Stock Exchanges in Fostering Economic Growth and Sustainable Development. Retrieved from https://unctad.org/en/PublicationsLibrary/WFE_UNCTAD_2017_ en.pdf

59. WFE Sustainability Survey. (2017, April). Exchanges Promoting Sustainability. Retrieved from 
https://www.world-exchanges. org/storage/app/media/research/ Studies_Reports/WFE\%20Annual\%20Sustainability\%20Survey $\% 202017 . p d f$

60. WFE, 2010 Exchanges, ESG and Investment Decisions. Retrieved from https://www.world-exchanges.org/storage/app/media/ research/Studies_Reports/2010- exchanges-esg-amp-investmentdecisions.pdf

61. Wu, M. W., \& Shen, CH. H. (2013). Corporate Social Responsibility in the Banking Industry: Motives and Financial Performance. Journal of Banking \& Finance, 37, 3529-3547. https://doi.org/10.1016/j.jbankfin.2013.04.023
62. Zheng Li. (2006). A Study on Relation of Corporate Social Responsibility and Corporate Value: Empirical Evidence from Shanghai Securities Exchange. China Industrial Economy, 2. http://en.cnki. com.cn/Article_en/CJFDTOTALGGYY200602009.htm 